\title{
Is it time to rethink the patient safety strategy approach?
}

\section{Mini review}

For over 90 years, concerns about the quality of health services have been documented with the publication of the Hospital Standardization Program (PPH) by the American College of Surgeons, which set standards to ensure the quality of patient care. In 1951, the Hospital Accreditation Commission (CCAH) was created in the USA and one year later transferred the Accreditation program to the Joint Commission on Accreditation of Hospitals, a private company whose mission was to introduce and emphasize the culture of quality to hospital medical culture. In 1970, this organization published the Accreditation Manual for Hospitals with quality standards that considered processes and results of health care and which has been improved periodically. ${ }^{1}$ Thereby, many publications on quality of health care have been published. Later on, Leape et al. ${ }^{2}$ and Brennan et al. ${ }^{3}$ specifically addressed the adverse events in a hospital environment.

The iconic report entitled "To Err is Human. Building a Safer Health System" by Kohn et al. ${ }^{4}$ in 1999 estimated that over 44,000 to 88,000 patients died in the USA triggering safety patient to the attention to many researchers trying to overcome this health care challenge. World Health Organization (WHO) recognized patient safety as a Global Health priority and in 2004 launched the World Alliance for Patient Safety with the purpose to disseminate patient safety concepts, and to improve patient safety worldwide. ${ }^{5}$ In 2009 , WHO also published a classification of patient safety incidents to expand the knowledge and to facilitate the design and the comparison of research results on it. ${ }^{6}$

In parallel, hundreds of hospitals in five continents, mainly in US and Europe, have been accredited for quality of their services by different agencies and patient safety has been included as one of dimensions of healthcare quality. ${ }^{7}$ Therefore, many countries have settled comprehensive strategies to address patient safety at a national level. From designing and implementing processes, continuous training, selecting indicators for monitoring quality of health and patient safety incidents, launching patient safety committees to WHO campaigns that approached top priorities in patient safety according to different levels of development of countries among other actions. For instance, in 2013, the Brazilian Ministry of Health, published the National Patient Safety Program, which establishes the Safety Nucleus of the patient should be implemented in all health facilities throughout the national territory. In the same year, it was also established that every health facility should develop a Patient Safety Plan to promote more safety for patients, professionals and the health care environment". ${ }^{8}$

Significant progress has been made so far in detecting patient safety incidents in a variety of scenarios demonstrated that the percentage of avoidable patient safety range from 7.6 to $67 \%$ of them related to surgery and clinical procedures..$^{9-11}$ Medical literature indicates human failure as the main cause of the patient safety incidents, conditioned to deficiencies in the care system, which are evidenced by the organization's strategies and culture, work practices, quality management approach, risk learning with errors. Failures associated
Volume 5 Issue I - 2018

Marcia Cristina Zago Novaretti, Renata
Mahfuz Daud-Gallotti
Dean of Executive Master in Health Systems Management,
Universidade Nove de Julho, Brazil

Correspondence: Marcia Cristina Zago Novaretti, Dean of Executive Master in Health Systems Management, Universidade Nove de Julho, Brazil, Email renatagallotti@uni9.pro.br

Received: August 01, 2017| Published: January 19, 2018

with infrastructure and equipment can also be related to incidents, but less often. ${ }^{12}$

The culture of patient safety has emerged as the main concern to avoid incidents that could generate damages due to the assistance, characterizing the adverse events. In recent years, a progressive number of studies on the subject has been observed, mainly in relation to the form of risk management, in which the notifications and the restructuring of processes that prevent new incidents or failures are encouraged. ${ }^{13}$ Errors must be considered as system failures and should be viewed as learning opportunities for prevention and improvement of the quality of care provided. However, despite innumerous efforts developed in many countries, in 2016 patient safety incidents were considered the third cause of death in the United States, which corroborates with the theory of James Reason, which accepts the human being as being error prone and, therefore, barriers must be created to avoid failures through a safety culture..$^{14,15}$

Therefore, the barriers already implemented worldwide in the last decade, although induced considerable advance in patient safety has been not sufficient to reduce, at least severe adverse events resulting in death in the USA. Could this be explained, in part, by the fragmented healthcare? Or due to expressive and time consuming bureaucratic activities? Or because IT systems can not actively avoid appropriately many adverse events as expected? Or due to fear of law suits? Or even due unnecessary laboratory and image exams and procedures increasing healthcare costs and limiting access to healthcare? Do health professionals listening patients' needs with time and patience? Can we consider, at this moment, in routine basis that patients are the center of health care?

Finally, there are plenty of areas to develop a better and safe care for patients, beginning with the proposal to consider patient as the center of care and to promote strategies to strength the relationship among patients and healthcare professionals integrating all of them in a transparent and humanistic system that provides healthcare.

\section{Acknowledgements}

None.

\section{Conflict of interest}

The author declares no conflict of interest. 


\section{References}

1. Roberts JS, Coale JG, Redman RR. A history of the Joint Commission on Accreditation of Hospitals. JAMA. 1987;258(7):936-940.

2. Leape LL, Brennan TA, Laird N, et al. The nature of adverse events in hospitalized patients: results of the Harvard Medical Practice Study II. $N$ Engl J Med. 1991;324(6):377-384.

3. Brennan TA, Leape LL, Laird NM, et al. Incidence of adverse events and negligence in hospitalized patients: results of the Harvard Medical Practice Study I. N Engl J Med. 1991;324(6):370-376.

4. Kohn LT, Corrigan JM, Donaldson MS. To Err is Human. Building a safer health system. Committee on quality of health care in America, USA: Academy Press; 1999.

5. Donaldson L, Philip P. Patient safety: a global priority. Bulletin of the World Health Organization. 2004;82(12):892-892.

6. World health organization. A world alliance for safer health care. More than words: conceptual framework for the international classification for patient safety. Geneva, Switzerland; Springer; 2009.

7. Reis CT, Martins M, Laguardia J. Patient safety as a dimension of the quality of health care: a look at the literature. Cien Saude Colet. 2013;18(7):2029-2036.

8. Resolução da diretoria colegiada-RDC no 36 , de 25 de julho de 2013 Institui ações para a segurança do paciente em serviços de saúde e dá outras providências. Brazil: Springre; 2013
9. Novaretti MCZ, Santos EDV, Quitério LM, et al. Nursing workload and occurrence of incidents and adverse events in ICU patients. Rev Bras Enferm. 2014;67(5):692-699.

10. Waldman CCS, Traverzin MADS, Novaretti MC. Identificando falhas no agendamento de cirurgias eletivas: a experiencia de um hospital publico. Rev Inov Proj E Tecnol S. 2015;3(1):1-16.

11. Mendes W, Martins M, Rozenfeld S, et al. The assessment of adverse events in hospitals in Brazil. Int J Qual Health Care. 2009;21(4):279284.

12. Cecchetto FH, Fachinelli TS, Souza EN. Iatrogenia ou evento adverso: percepção da equipe de enfermagem. Rev enferm UFPE. 2010;4(3):13771383.

13. Gregory N Stock, Kathleen L, McFadden. Improving service operations: linking safety culture to hospital performance. Journal of Service Management. 2017;8(1):57-84.

14. Makary MA, Daniel M. Medical error-the third leading cause of death in the US. BMJ: British Medical Journal. 2016. 353 p.

15. Reason J. Human error: models and management. BMJ. 2000;320(7237):768-770. 